Окландер М.А.

доктор економ. наук, професор,

Одеський національний політехнічний університет

Романенко 0.0.

канд. економ. наук, дочент,

Київський національний лінгвістичний університет

\title{
СПЕЦИФІЧНІ ВІДМІННОСТІ ЦИФРОВОГО МАРКЕТИНГУ ВІД IНTЕРНЕТ-МАРКЕТИНГУ
}

\section{СПЕЦИФИЧЕСКИЕ ОТЛИЧИЯ ЦИФРОВОЙ МАРКЕТИНГА ОТ ИНТЕРНЕТ- МАРКЕТИНГА}

\section{SPECIFIC DIFFERENCES IN DIGITAL MARKETING FROM INTERNET MARKETING}

B статті розглянуто теоретичні положення цифрового маркетингу як специфічної форми класичного маркетингу в умовах зміни технологічного базису виробництва та інформатизації суспільства. Обтрунтовано, щуо ииффровий маркетинг збагатив Інтернет-маркетинг можливостями мобільного зв'язку. Показано, що цчифрові методи обробки та використання інформаиї стають основним джерелом підвищення результативності і ефективності маркетингової діяльності. Доведено, щуо в результаті з'явились додаткові можливості розширення аудиторії маркетингового впливу за рахунок власників засобів мобільного зв'язку з одночасним забезпеченням адресності та персоніфікаиї такого впливу. Акцентована увага на змінах форм і методів маркетингової діяльності, які стають поштовхом для появи нової форми маркетингової діяльності. Визначено, щзо изифровий маркетинг $є$ видом маркетингової діяльності, який за циифровими каналами циифровими методами дозволяє адресно взаємодіяти з ичільовими сегментам ринку у віртуальному та реальному середовищах.

Ключові слова: Інтернет-маркетинг, цифровий маркетинг, електронна комерція, соціальні мережі, таргетинг, веб-ресурс.

В статье рассмотрены теоретические положения цифррового маркетинга как специфической формы классического маркетинга в условиях изменения технологического базиса производства и информатизации общества. Обосновано, что ичифровой маркетинг обогатил Интернет-маркетинг возможностями мобильной связи. Показано, что цифрровые методы обработки и использования информации становятся основным источником повышения результативности $и$ эффективности маркетинговой деятельности. Доказано, что в результате появились дополнительные возможности расширения аудитории маркетингового воздействия за счет владельцев средств мобильной связи с одновременным обеспечением адресности и персонификачии такого воздействия. Акиентировано внимание на изменениях форм и методов маркетинговой деятельности, которые становятся толчком для появления новой формы маркетинговой деятельности. Цифровой маркетинг определен, как вид маркетинговой деятельности, который по цифрровым каналам циирровыми методами позволяет адресно взаимодействовать с иелевыми сегментам рынка в виртуальной и реальной средах.

Ключевые слова: Интернет-маркетинг, цифровой маркетинг, электронная коммерция, социальные сети, таргетинг, веб-ресурс. 
The article describes the theoretical principles of digital marketing as a specific form of classical marketing in a changing technological basis of production and the information society. Substantiated that digital marketing has enriched Internet marketing capabilities of mobile communication. It is shown that digital processing techniques and the use of information become the main source of increasing the effectiveness and efficiency of marketing activities. We prove that as a result there are additional possibilities of expanding the audience of the marketing impact by owners of mobile communications with simultaneous targeting and personalization of such exposure. The attention is focused on the changes of forms and methods of marketing activities, which become the impetus for the emergence of new forms of marketing activities. Digital marketing is defined as a kind of marketing activities, which on digital channels digitally addressable allows to interact with the target market segment in virtual and real environments.

Keywords: Internet marketing, digital marketing, e-commerce, social networks, targeting, web resource.

Вступ. Інтернет-маркетинг виник в межах функціонування електронної економіки, концепцію якої у 1995 р сформулював Негропонте Н., який узагальнив нові риси економічного існування цивілізації. Інтенсивне кількісно-якісне зростання користувачів Інтернет 3 кінця 80-х років XX ст. забезпечувалось його комунікаційними функціями i можливостями економічної взаємодії. Освоєння Інтернет i формування електронної економіки розпочалося 3 електронної пошти, продовжилось можливостями передачі інформації, появою електронної комерції, Інтернет-банкінгу. У 1994 p. був відкритий перший Інтернет-магазин i впроваджена перша система Інтернет-банкінгу. Після вдалого початку можливості Інтернет стали масштабно використовуватись підприємствами всіх секторів і галузей економіки.

Підприємства почали створювати сайти і впроваджувати електронні форми ведення бізнесу. Вільний доступ до Інтернет породжував більш ефективні форми господарської діяльності, створював додаткові канали постачання і розподілу. Безперервне зростання користувачів Інтернет, кожен 3 яких $\epsilon$ потенційним споживачем, призвели до адекватного зростання товарообігу електронної економіки. Різке зниження трансакційних витрат автоматично підвищувало рентабельність господарської діяльності, що за каналами зворотнього зв'язку призвело до вибухоподібного зростання кількості віртуальних підприємств: банків, магазинів, представництв, аукціонів. Віртуальне середовище, віртуальні підприємства простимулювали виникнення віртуальних товарів (програмне забезпечення, сайти, комп'ютерні ігри) і грошей. Віртуальні товари та електронні гроші $\epsilon$ унікальними феноменами електронної економіки, які не існують окремо від виробничих сил електронної економіки (комп'терних приладів та засобів телекомунікації). Електронна економіка самоідентифікувалась, отримавши специфічні відмінності від реальної економіки, що різко прискорило темпи іiі зростання. Виникли галузі галузі електронної економіки: 1) електронна комерція (е- commerce); 2) електронні гроші (e-cash); 3) електронний маркетинг (e-marketing); 4) електронний банкінг (e-banking); 5) електронне страхування (e-insurance). 
Теоретичні засади формування маркетингових технологій у віртуальному середовищі знайшли відображення у наукових працях таких вчених як Р. Абдеєв, Д. Белл, Г. Васильєв, В. Голик, Ф. Гуров, Д. Забегалін, М. Зуєв, М. Івченко, Е. Кінг, Т. Козлова, П. Маурус, І. Мелюхин, І. Бойчук, В. Пилипчук, А. Прокоф'єв, Є. Путилова, Дж. Райт, Р. Реддік, М. Хейг, А. Шеремет. Разом із тим, теоретичне усвідомлення та наукове обгрунтування місця маркетингу в умовах інформатизації суспільства залишається предметом наукової дискусії.

«Наріжним каменем» електронної економіки є Інтернет. Тому типове визначення електронної економіки пов'язане з Інтернет і формулюється наступним чином: «Електронна економіка - це економіка, в якій головні виробничі функції зосереджені в електронній комерції, наприклад, торгівля в Інтернет» [1]. Двадцятирічний досвід електронної економіки викликав явище переходу кількісних змін у якісні - з'явилася цифрова еконоімка. За законами діалектики епоха цифрової економіки змінює епоху Інтернетекономіки. Позитивне переходить в нову епоху, а трансформації відбуваються за рахунок заперечення неефективного та переходу кількості в якість. «Цифрова економіка - це глобальна мережа економічної і соціальної діяльності, яка доступна через такі платформи як Інтернет, мобільні i

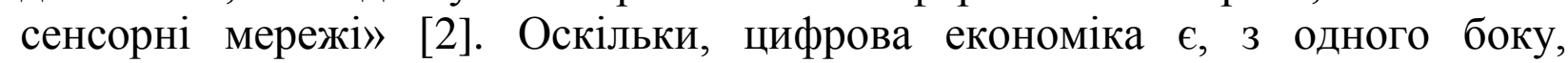
похідною від електронної економіки, а 3 іншого, наступним етапом розвитку то, невирішеним є виділення принципових відмінностей маркетингу в умовах цифрової економіки.

Постановка задачі. Метою статті $\epsilon$ визначення специфічних відмінностей цифрового маркетингу від Інтернет-маркетингу.

Методологія. У роботі було використано методи наукової абстракції, аналізу та синтезу, системний, діалектичний, аналогії та структурнофункціональний методи дослідження, що дають можливість розкрити сутність трансформації культурних чинників поведінки споживача в сучасних умовах.

Результати дослідження. Із Інтернет-економіки в цифрову економіку переходять наступні характеристики: масштаб операційної діяльності не $\epsilon$ залежним від розміру і місцезнаходження; інформація є відновлювальним ресурсом, який може бути використаний багато разів; внаслідок підвищеної інформованості споживачів їх поведінка стає проактивною.

Новими явищами, які надають цифровій економіці самостійність та специфічність, $\epsilon$ :

- мобільні технології;

- хмарні технології;

— бізнес-аналітика на основі цифрових технологій;

- соціальні медіа.

Мобільні технології істотно змінюють бізнес-моделі, оскільки різноманітні дії з інформацією можна здійснювати дистанційно. Смартфони $є$ персоніфікованим багатофункціональним мережевим пристроєм, який має широкий спектр додатків, відеокамери, фотокамери, дозволяє з'єднуватися 3 
усіма приладами в Інтернет, з іншими людьми. В 2017 р. у світі буде близько 2,5 млрд. власників смартфонів (рис. 1).

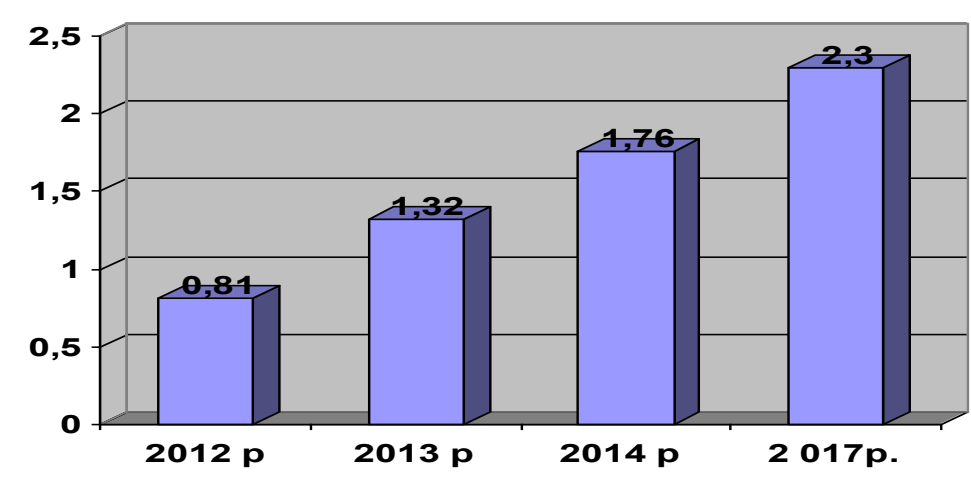

Рис. 1. Динаміка кількості власників смартфонів у світі [3]

Чим вищі темпи зростання економікі, тим швидше збільшується кількість смартфонів. В 2014 р. економіка Китаю вийшла на перше місце в світі за темпами зростання, відповідно, Китай займає переше місце в світі за кількістю власників смартфонів. На другому місці економіка США - США займає друге місце за кількістю власників смартфонів.

Хмарні технології дозволяють обробляти великі масиви несистематизованої інформації, систематизуючи іiі. Безумовно це полегшує прийняття маркетингових рішень. Тому в світі зростають витрати на впровадження хмарних сервисів (рис. 2).

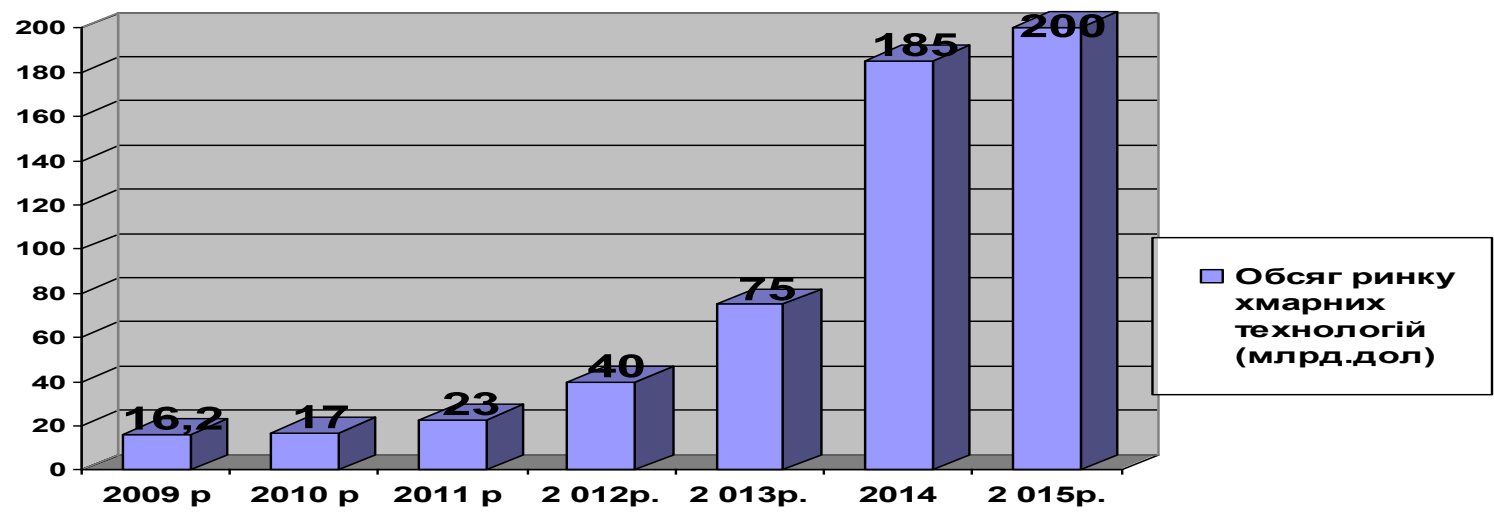

Рис. 2. Динаміка обсягу світового ринку хмарних технологій [4]

У 2015 році до 60\% зібраної в світі інформації зберігатиметься у хмарах. В США та країнах СС прийняті національні програми розвитку хмарних сервісів: в США — «Федеральна стратегія щодо хмарних обчислень»; в $\mathrm{CC}$ - «Вивільнення потенціалу хмарних обчислень в Свропі» (2,5 млн. додаткових робочих місць, 160 млрд. євро щорічного додаткового прибутку) [5].

Розвиток хмарних технологій змінює форми і зміст аналітичної діяльності в підприємництві. Нині обсяги несистематизованої, незадокументованої інформації зростають в 2-2,5 рази більше, ніж 
задокументованої. Тому адекватно зростає значення сучасної бізнесаналітики (рис. 3).

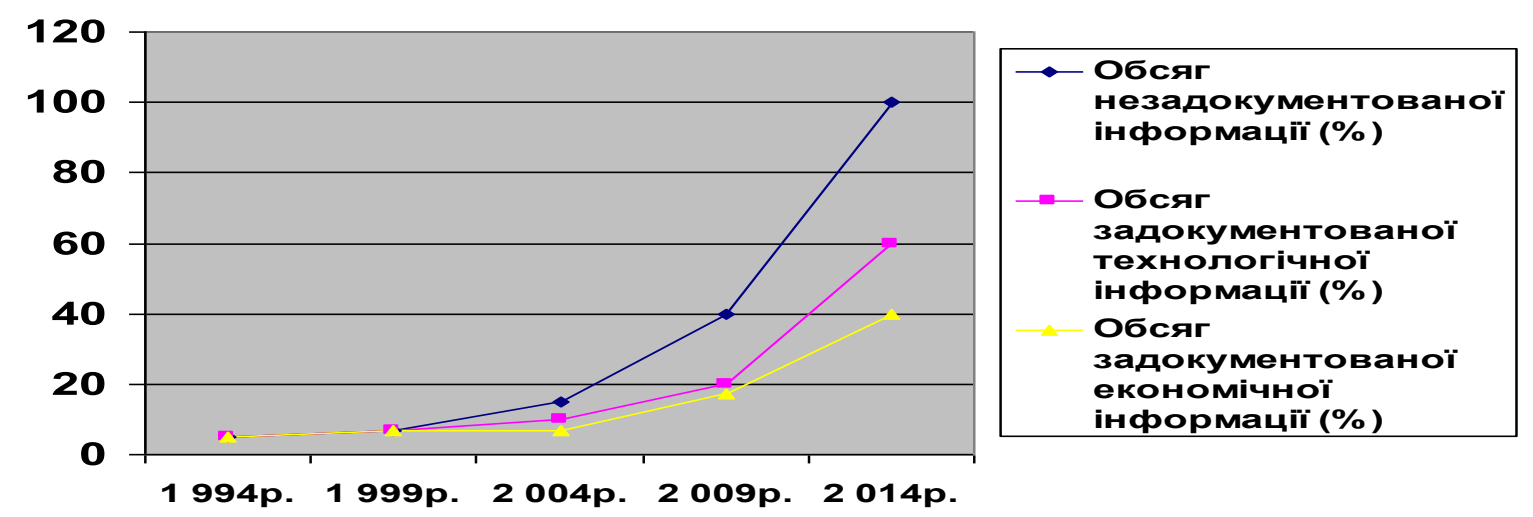

Рис. 3. Динаміка генерування інформації (\%) [6]

Бізнес-аналітика на основі цифрових технологій змінює традиційну, розтягнуту в часі, схему аналітичної роботи: інформація певний час збиралась, а потім аналізувалась. Нині важливим є автоматичний мережевий аналіз потоку незадокументованих даних, що мають пряме чи опосередковане відношення до підприємства. Інструментами бізнесаналітики $є$ : платформи бізнес-аналітики (business intelligence, BI), інструменти управління ефективністю діяльності (corporate performance management, CPM), розширені аналітичні додатки. Світовий ринок програмного забезпечення бізнес-аналітики складає 14,4 млрд. I, в середньому, щорічно зростає на 8\%. Найбільшими спеціалізованими виробниками є SAP та Microsoft [7].

Соціальні медіа гармонізують міжфункціональну координацію підрозділів підприємств та зв'язок із споживачами та партнерами. Зростання соціальних мереж останнім часом обумовлено двома чинниками: збільшенням кількості осіб, які підключаються до Інтернет через мобільні телефони та зростанням аудиторії соціальних мереж за рахунок осіб старших вікових категорій (табл. 1).

Таблиця 1

Параметри основних соціальних мереж

\begin{tabular}{|l|c|c|l|}
\hline $\begin{array}{c}\text { Назва } \\
\text { соціальної } \\
\text { мережі }\end{array}$ & $\begin{array}{c}\text { Кількість } \\
\text { відвідувачів } \\
\text { в день, } \\
\text { млн. осіб }\end{array}$ & $\begin{array}{c}\text { Кількість } \\
\text { унікальних } \\
\text { відвідувачів в } \\
\text { місяць, млн. } \\
\text { осіб }\end{array}$ & \multicolumn{1}{|c|}{ Характеристика аудиторії } \\
\hline Facebook & 665 & 900 & $\begin{array}{l}\text { Найшвидше зростаючим сегментом } є \text { особи } \\
\text { в віці 45-54 роки }\end{array}$ \\
\hline Twitter & 35 & 500 & $\begin{array}{l}\text { Найшвидше зростаючим сегментом } є \text { особи } \\
\text { в віці 55-64 роки }\end{array}$ \\
\hline YouTube & - & 1000 & $\begin{array}{l}\text { Найшвидше зростаючим сегментом } є \text { особи } \\
\text { в віці 18-34 роки }\end{array}$ \\
\hline Google+ & 120 & 359 & $\begin{array}{l}\text { Найшвидше зростаючим сегментом } є \text { особи } \\
\text { в віці 45-54 роки }\end{array}$ \\
\hline
\end{tabular}




\begin{tabular}{|l|c|c|l|}
\hline LinkedIn & 9 & 200 & Найбільша світова професійна мережа \\
\hline Вконтакте & 60 & 160 & $\begin{array}{l}\text { Найшвидше зростаючим сегментом є жінки } \\
\text { в віці 55-65 років }\end{array}$ \\
\hline
\end{tabular}

Зрозуміло, що концепція та методологія маркетингу носять універсальний характер i спрямовуються на підвищення конкурентоспроможності підприємств. Однак в сучасних умовах цифрової економіки класичні теоретичні положення маркетингу набувають специфічних форм, адаптуючись до зміни технологічного базису виробництва. Зростає потужність комп'ютерів i обсяг накопиченої інформації, дешевшим стає процес зберігання даних.

Нові цифрові методи обробки та використання інформації стають основним джерелом підвищення результативності та ефективності маркетингової діяльності. В умовах інформатизації суспільства, Інтернет та інші цифрові канали змінюють форми і методи маркетингової діяльності, стають поштовхом для появи нової форми маркетингової діяльності цифрового маркетингу (англ. digital marketing).

Данько Т.П., Китова О.В. вважають, що «цифровий маркетинг — це маркетинг, що забезпечує взаємодію 3 клієнтами та бізнес-партнерами 3 використанням цифрових інформаційно-комунікаційних технологій та електронних пристроїв, більш широкому сенсі це... реалізація маркетингової діяльності 3 використанням цифрових інформаційно-комунікаційних технологій» [8, С. 261].

Карпіщенко О.О., Логінова Ю.Е. зазначають, що «цифровий маркетинг - це використання всіх можливих форм цифрових каналів для просування фірми та іï товару. Телебачення, радіо, Інтернет, соціальні медіа - усе це інструменти цифрового маркетингу. Цифровий маркетинг тісно переплітається 3 Інтернет маркетингом, але в ньому вже розроблені ряд технік, що дозволяють досягати цільову аудиторію навіть в офлайн середовищі». Він вирішує наступні завдання: 1) підтримка іміджу бренду; 2) підтримка виведення нового бренду або продукту на ринок; 3) підвищення впізнаваності; 4) стимулювання продажів [9].

На нашу думку, цифровий маркетинг - це вид маркетингової діяльності, що за цифровими каналами цифровими методами дозволяє адресно взаємодіяти 3 цільовими сегментам ринку у віртуальному та реальному середовищах.

Цифровий маркетинг — це весь комплекс маркетингових дій в сучасному світі. Тобто, це сучасний маркетинг, якому властива дуальність через його гібридний характер: частина функцій виконується в он-лайн, а частина в оффлайн-середовищі.

Цифровий маркетинг є похідним від Інтернет-маркетингу, виходячи, при цьому, за межі комп’ютерного спілкування. Взаємодія 3 цільовими аудиторіями відбувається за рахунок мобільних пристроїв, цифрового телебачення, інтерактивних екранів, POS-терміналів. Якщо в Інтернетмаркетингу використовується один канал - Інтернет, то у цифровому 
маркетингу кількість каналів є достатньо великою і в перспективі буде зростати. Крім того, високими темпами зростають кількість мобільних пристроїв (рис. 4).

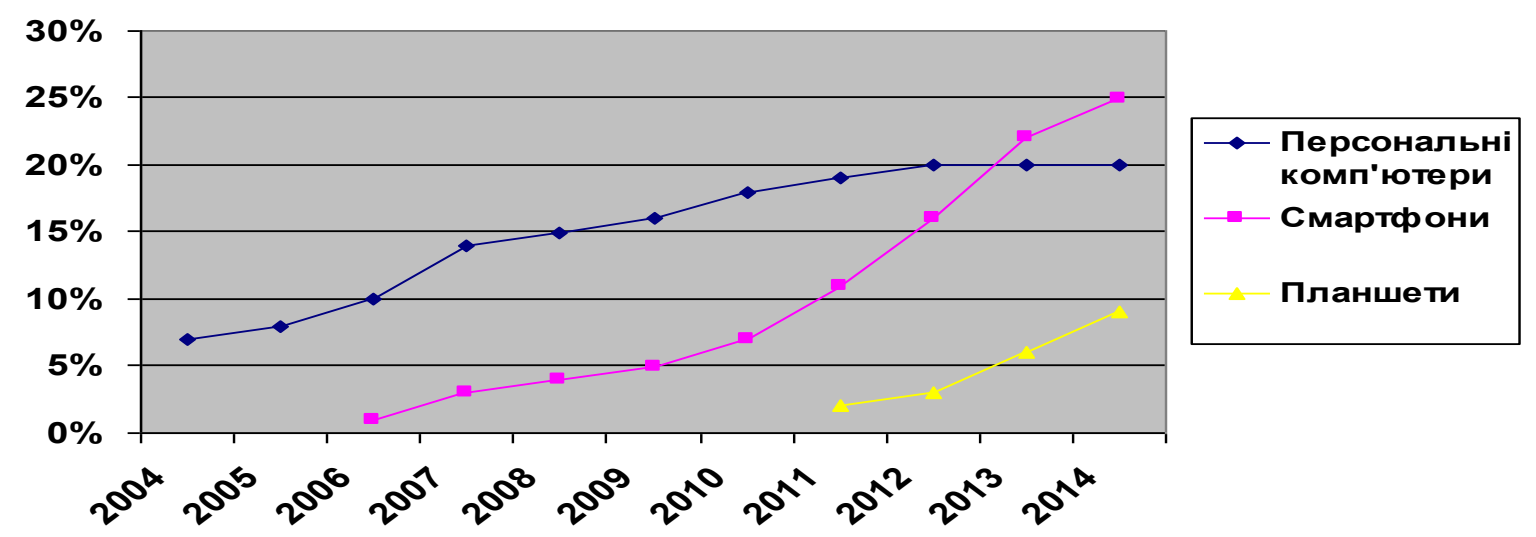

Рис. 4. Частка пристроїв до кількості населення в світі [10] каналів:

В теперішній час цифровий маркетинг використовує п'ять цифрових

1) мережа Інтернет і пристрої, що надають доступ до неї (комп'ютери, планшети, смартфони);

2) локальні мережі (Екстранет, Інтранет);

3) мобільні пристрої;

4) цифрове телебачення;

5) інтерактивні екрани, POS-термінали.

Цифровий маркетинг є другою фазою розвитку маркетингу в умовах інформатизації суспільства. Цифрові канали забезпечують практично миттєве поширення інформації, стають основним носієм комунікативних повідомлень та механізмом взаємодії 3 клієнтом. Тому важливою $\epsilon$ присутність підприємства у вказаних цифрових каналах. Він має унікальні властивості, що обумовлені гіпермедійною природою. Аудіовізуальні цифрові методи дозволяють здійснювати ефективний емоційний, когнітивний, психологічний вплив на цільову аудиторію, отримувати доступ до інформації без обмежень місцезнаходження комп'ютера (web-i wapресурси), долати територіальні бар'єри на шляху реалізації маркетингових заходів, скорочувати часові витрати на доступ до каталогів товарів, адаптивно реагувати на появу потреб та побажань клієнтів і бізнес-партнерів, управління подіями в режимі реального часу.

Аудіовізуальні можливості цифрового маркетингу стимулюють підвищення інтересу споживачів до рекламованого товару, адже візуальне зображення сприймається у 6000 разів швидше, ніж текстове:

- збільшується конверсія, якщо зображення супроводжує рекламне повідомлення;

— збільшується кількість відвідувачів сайту, якщо на головній сторінці $\epsilon$ відео- чи анімаційний ролик; 
- підвищується імідж та відомість підприємства, якщо воно пропонує безкоштовні сервіси по обміну фотографіями і відео;

- збільшуються продажі, якщо підприємство присутнє у соціальних мережах та має блоги, які ведуть провідні фахівці та керівники підприємства.

Основними методами цифрового маркетингу є:

— контекстна реклама Google Adwords, Yandex Direct;

— технологія Big Data - масиви даних великих обсягів;

— ретаргетінг (англ. retargeting) — перенацілювання;

- мобільний маркетинг;

- електронна пошта;

- вірусний маркетинг.

— RTB (англ. real time bidding) — торги в реальному часі;

- SMM (англ. social media marketing) — соціальний медіа маркетинг;

— SMO (англ. social media optimization) — оптимізація для соціальних мереж;

— SEO (англ. search engines optimization) — оптимізація сайту у пошукових системах;

— SEM (англ. search engine marketing) — пошуковий маркетинг.

Рейтинг частоти використання методів цифрового маркетингу виглядає наступним чином: перше місце - SEO (оптимізація сайту у пошукових системах) — цей метод застосовують 90\% підприємств; друге місце - SMM (соціальний медіа маркетинг) i SMO (оптимізація для соціальних мереж) 65\% підприємств; третє місце - контекстна реклама - 60\% підприємств; четверте місце - SEM (пошуковий маркетинг) - 33\% підприємств [11].

Перше місце пошукової оптимізації пояснюється тим, що 70-90\% споживачів, в залежності від типу ринку (В2С, В2В) починають пошук товару $з$ пошукових систем. На цьому грунтується парадигма і концепція цифрового маркетингу, які проявляються у філософії: «Співпрацюй з тими, хто цього хоче». Саме такий підхід апріорі $є$ найбільш ефективним.

Коли користувач звертається до пошукової системи, то його запит фіксується i таким чином визначаються потреби споживачів. Далі за допомогою інших інструментів цифрового маркетингу йому пропонують альтернативні варіанти задоволення попиту. Тому цифровий маркетинг часто називають інбаунд (англ. inbound — вхідний) чи пулл (англ. pull — тянучий). На відміну від традиційного маркетингу, який за своєю суттю $є$ аутбаундом (англ. outbound - вихідний) чи пуш (англ. push - штовхаючий). Отже, цифровий маркетинг активізується після появи інтересу у потенційного покупця, а сигналом до початку активної фази цифрового маркетингу $є$ подача запиту до пошукових систем. Значення пошукових систем, а, значить i SEO-оптимізації, буде зростати.

Друге місце маркетингової діяльності в соціальних мережах обумовлено популярністю соціальних мереж та високим рівнем довіри до рекомендацій знайомих і друзів. Соціальні мережі є штучною платформою для реалізації біосоціальної схильності людей до спілкування. Цьому сприяють необмежені інтерактивні комунікації, безпосередня участь 
користувачів в генерації та ретрансляції медійного контенту, високий ступінь залученості в процес комунікацій, максимальна швидкість зворотного зв'язку, персоналізація користувача. Рекламі довіряють лише 14\% покупців, а відгукам інших споживачів - 78\% покупців [12]. Між тим, окрім соціальних мереж $\epsilon$ інші різновиди соціальних медіа, які також дозволяють впливати на позицію споживачів: Інтернет-форуми, блоги, фото- та відео- хостинги, віртуальні світи, спільноти 3 виробництва спільного контенту, спільні проекти, геосоціальні сервіси, спільноти подієвих комунікацій, сайти знайомств, соціальні агрегатори. Тому такими важливими є методи SMM i $\mathrm{SMO}$, які дозволяють формувати і закріплювати позитивний імідж підприємства серед мережевої спільноти за рахунок організації медіамайданчиків і залучення на них цільової аудиторії, розміщення рекламного чи PR-контенту в місцях концентрації цільової аудиторії, створення та управління блогами, співпраці з блогерами, створення або спонсорування додаткових програмних продуктів, проведення конкурсів, френдингу, розсилки інвайтів.

Додатковим інструментом для соціальних мереж є вірусний маркетинг, який $\epsilon$ вкрай ефективним при умові гармонізації змісту комерційної інформації та форми іiї ілюстрації (ролики, тексти, фотографії). Вдалий вибір форми простимулює споживачів добровільно пересилати їх іншим відвідувачам соціальних мереж. Найбільшу комунікативну ефективність мають: смішні-, драматичні-, екстремальні-, хорор-ролики.

Мобільний маркетинг, поки що не входить до лідерів цифрового маркетингу, проте стрімко набирає темпи і найближчим часом слід очікувати зростання його частки в загальному обсязі реклами. Нарощування потенціалу мобільних пристроїв, зростання кількості GPS-пристроїв та різноманітних мобільних додатків призведе до реструктуризації цифрового маркетингу на користь мобільного маркетингу. Мобільний маркетинг у 2-5 разів ефективніший Інтернет-маркетингу [13]. Перспективним $є$ використання мобільного маркетингу з географічною прив'язкою на основі GPS-пристроїв.

В 2014 році, за оцінками eMarketer, компанії всього світу планують витратити на цифровий маркетинг 135 млрд. дол. В 2015 році, за прогнозами WebDAM Solutions, цифровий маркетинг займе 25\% від загального обсягу маркетингових бюджетів, при цьому доходи від реклами у друкованих засобах масової інформації демонструють показники рівня середини XX ст. і ця тенденція буде наростати [12].

Цифровий маркетинг ширший за Інтернет-маркетинг на:

1) нові можливості мобільного зв'язку:

- текстові повідомлення (SMS);

- голосове автоматичне меню (IVR);

- мультимедійні повідомлення (MMS);

— локальний радіозв'язок між комунікаційними засобами (Bluetooth);

— безпровідний протокол передачі даних (WAP);

- мобікод - комбінація цифр, яка надає можливість здійснювати платежі чи отримувати знижки; 
— QR-код — картинка на друкованій продукції, яка дозволяє швидкий перехід у віртуальне середовище;

— технології Click To, Flash SMS, Location Based Services (LBS) технології зручного завантаження програмних продуктів;

2) нові можливості телебачення:

- технологія доповненої реальності (Augmented Reality) — технологія відтворення у реальності віртуальних елементів;

3) нові можливості інтерактивних екранів:

- 3D-проекції (3D-mapping) - технологія проекції зображення на об'єкт навколишнього середовища;

4) нові можливості POS-терміналів, відеокамер:

- біометричні технології - технологія автоматизованої ідентифікації споживачів, на основі фізіологічних (відбитки пальців, розпізнавання обличчя, ДНК, малюнок райдужної оболонки ока, форма долоні або вуха, запах) або поведінкових (рукописний або клавіатурний почерк, голос, рух губ, хода) характеристик. Наприклад, за допомогою біометричних технологій можна оплачувати товари, приклавши палець (око, вухо) до сканеру. Відповідні камери дозволяють проводити маркетингові дослідження відношення до товару чи рекламних повідомлень у формі спостережень демографічних та поведінкових особливостей споживачів (повороти голови, моргання очей, рухи, міміка, хода, емоційні реакції). На основі цієї технології деякі торгові точки вже використовують розпізнавання обличчя для створення баз даних клієнтів.

5) нові можливості електронної пошти:

- розсилання на мобільні пристрої електронних рекламних повідомлень у вигляді sms, тобто відбувається комбінування телефонного маркетингу із поштовою розсилкою.

3 урахуванням цих можливостей змінюються роль сайту підприємства в системі цифрового маркетингу, який стає «серцево-судинною системою» цифрового маркетингу.

Сайт $є$ майданчиком, який дозволяє взаємодіяти із соціальними мережами, мобільними пристроями, забезпечує трафік користувачів та вимірювання відвідувань та дій. Удосконалення технологій дозволяє змінювати контент. Відбувається перехід від текстового наповнювання до відео, прив'язки до QR-кодів, інфографіки, фото, карт навігації, порівняльного аналізу товарів.

Залучення та утримання користувачів на сайті потребує розміщення актуальної змістовної інформації щодо підприємства та заходів по стимулюванню збуту. Важливою перевагою сайту $є$ можливість швидко змінювати позиціонування товару, залучати лояльних споживачів до співробітництва 3 підприємством, підвищувати обізнаність споживачів і формувати імідж «прозорого» соціально-відповідального підприємства, забезпечити доступність керівництва та співробітників для споживачів. 
Система оцінки комунікативної діяльності в системі цифрового маркетингу може складатися 3 наступних традиційних (класичних) та новітніх (специфічних) медіапоказників:

1) традиційні (класичні) показники:

— охоплення - частка цільової аудиторії, яка була піддана впливу рекламного повідомлення в певний проміжок часу;

- OTS чи частота (англ. opportunities to see - можливість побачити) — кількість переданих рекламних повідомлень за певний проміжок часу;

- GRP чи сумарний рейтинг (англ. gross rating points) - показник виконання медіаплану, розраховується як результат множення охоплення на частоту.

2) новітні (специфічні) показники інтерактивної взаємодії:

— наведення курсору — рух курсору по інтерактивному об'єкту;

— клік — клацання мишкою по інтерактивному об'єкту;

— переходи — переміщення користувача в результаті кліка на іншу URL-адресу;

- генерований користувачем контент — коментарі, посилання, які створює користувач; контенту.

— реєстрації в CMS-системі — акт, що забезпечує редагування

Конкуренція сприяє зростанню цифрових технологій, що робить їх основними інструментами в боротьбі за споживача - не тільки в якості медійного каналу, як основного засобу взаємодії з клієнтом через сервіси і додатки. При цьому використання набору методів цифрового маркетингу залежить від специфіки товару: майже 30\% товарів попереднього вибору (особливо електронна техніка) продається через Інтернет, для товарів повсякденного попиту такий показник ледь сягає $1 \%$.

Характеристиками цільових аудиторій, на які може бути спрямований цифровий маркетинг, $\epsilon$ :

- технологічна оснащеність: наявність мобільного телефону, комп'ютера, смартфону, планшету, телевізора 3 виходом в Інтернет, інтерактивної телевізійної приставки;

- економічна можливість: здатність оплачувати доступ до Інтернет, цифрового телебачення, GPRS-, WAP-, SMS-трафіки;

- вміння працювати в режимі користувача: вміння i навики користування цифровими терміналами;

— лояльність до цифрового каналу: а) сталі уподобання з використання цифрових каналів (не мають бажання переключатися на інші цифрові канали); б) мінливі уподобання 3 використання цифрових каналів (готові переключатися на інші цифрові канали);

- параметри об'єкту таргетування: географічні, галузеві, демографічні, психографічні ознаки;

- тип клієнтури: юридичні особи, фізичні особи.

В сучасних умовах інформатизації суспільства пропонується виділяти дві фази розвитку маркетингу (табл. 2). 
Перша фаза - Інтернет-маркетинг (1995-2003рр.), який розповсюджувався через стаціонарні комп'ютери, ноутбуки, функціонував у віртуальному середовищі, а цільовою аудиторією були лише власники комп'ютерів і ноутбуків з доступом до Інтернет.

Таблиця 2

Фази розвитку маркетингу в умовах інформатизації суспільства

\begin{tabular}{|c|c|c|c|}
\hline $\begin{array}{l}\text { № } \\
\Pi / \Pi\end{array}$ & Фаза & Період & Характеристика \\
\hline 1 & $\begin{array}{l}\text { Інтернет- } \\
\text { маркетинг }\end{array}$ & 1995-2003 pp. & $\begin{array}{l}\text { Канал розповсюдження: } \\
\text { Інтернет через стаціонарні комп'ютери, ноутбуки } \\
\text { Середовище функціонування: } \\
\text { віртуальне } \\
\text { Цільова аудиторія: } \\
\text { власники комп'ютерів і ноутбуків з доступом до } \\
\text { Інтернет }\end{array}$ \\
\hline 2 & $\begin{array}{l}\text { Цифровий } \\
\text { маркетинг }\end{array}$ & $\begin{array}{l}\text { 2003- } \\
\text { теперішній } \\
\text { час }\end{array}$ & $\begin{array}{l}\text { Канали розповсюдження: } \\
\text { 1) Інтернет через стаціонарні комп’ютери, } \\
\text { ноутбуки, } \\
\text { планшети, смартфони } \\
\text { 2) мобільні пристрої } \\
\text { 3) цифрове телебачення } \\
\text { 4) інтерактивні екрани, POS-термінали } \\
\text { Середовище функціонування: } \\
\text { 1) реальне } \\
\text { 2) віртуальне } \\
\text { Цільова аудиторія: } \\
\text { 1) власники комп’ютерів, ноутбуків, мобільних } \\
\text { телефонів, смартфонів, планшетів, телевізорів } 3 \\
\text { доступом до Інтернет } \\
\text { 2) власники мобільних телефонів, смартфонів } \\
\text { 3) користувачі послуг терміналів } \\
\text { 4) особи, які бачать електронні екрани }\end{array}$ \\
\hline
\end{tabular}

Друга фаза - цифровий маркетинг (2003 р. до теперішнього часу), який розповсюджується через всі мобільні пристрої та інші пристрої, що мають доступ до Інтернет, сфера функціонування розширюється за рахунок переходу у реальне середовище, а цільова аудиторія - за рахунок власників мобільних пристроїв.

Фалгоні Ж. вважає, що існують такі проблеми впровадження методів цифрового маркетингу в діяльність підприємств [15]:

1) Проблема відсутності фахівців. Існує дефіцит маркетологіваналітиків і фахівців 3 IT-технологій для опрацювання великих обсягів накопиченої маркетингової інформації - згідно даних консалтингової агенції McKinsey, лише в США необхідно 140 тис. провідних аналітиків і 1,5 млн. допоміжного аналітичного персоналу для аналізу масиву великих даних.

2) Проблема електронної комерції. Зростання обсягів електронної комерції зменшує рентабельність трансакційних операцій ритейлу внаслідок зниження цін - на споживчому ринку США обсяги продажів через Інтернет 
зросли на $15 \%$, що в п’ять разів перевищує приріст продажів у традиційній роздрібній торгівлі. Взагалі $10 \%$ роздрібного товарообігу США зосереджено в Інтернет.

3) Проблема соціальних мереж. Не існує методики оцінки ефективності маркетингової діяльності в соціальних мережах. При зростанні масштабів використання соціальних мереж (на території США за рік Facebook залучив 150 млн., LinkedIn - 41 млн., Twitter - 40 млн., Google + — 29 млн., Pinterest i Instagram - по 25 млн. відвідувачів; час відвідання соціальних мереж вже перевищив час відвідання сайтів) зрозуміло, що скупчення потенційної цільової аудиторії на певних мережевих майданчиках дозволяє проводити там маркетингові дослідження та комунікаційні заходи. Проте ефективність цих заходів важко оцінити i деякі фахівці навіть вважають, що така ефективність $\epsilon$ вкрай невисокою.

4) Проблема зростання витрат на цифрову рекламу. Збільшення попиту на розміщення реклами в Інтернет і іiі відносна ефективність стимулює зростання цін неї. Звіт Бюро інтерактивної реклами (IAB — міжнародна суспільна організація, яка об’єднує виробників цифрової реклами), вказує на значне зростання обсягів реклами в самих різних цифрових форматах, особливо в мобільному маркетингу $(+92 \%)$, відеороликів (+ 18\%), пошукових системах (+ 17\%), банерах (+ 12\%). Прогнозується, що у відносно короткій перспективі вартість відеороліків у Інтернет перевищить вартість реклами на телебаченні.

5) Проблеми таргетингу і ретаргетингу. Дані технології є ефективними, проте вихід на ринок таргетування значної кількості операторів знижує ціни і рентабельність цієї діяльності. Тому виникає протиріччя: 3 одного боку, таргетування вигідно рекламодавцям, а 3 іншого - зацікавленість провайдерів цієї послуги знижується.

6) Проблема вимірювання ефективності цифрових рекламних повідомлень. Найбільші міжнародні представники світового рекламного бізнесу, розуміючи, що підвищення ефективності рекламної діяльності на основі цифрових носіїв можливе після подолання конфлікту між кількістю «показаних» і кількістю «побачених» рекламних оголошень, запустили ініціативу 3MS (англ. Making Measurement Make Sense - «Наповнити показники реальним змістом»). Одна з ключових завдань проекту: розробити інструментарій вимірювання рекламних оголошень, які не просто з'явились на екрані, а були побачені та прочитані. 3 досліджень роликів, які отримали мільярди переглядів, було з'ясовано, що в середньому біля $30 \%$ рекламних оголошень, які були розміщені на переглянутих сторінках, користувач не побачив. Це відбувається тому, що користувач не прокручує сторінку до кінця або покидає іï швидше, ніж завантажується реклама. В результаті починається розробка спеціальних програм, які гарантують обов'язкове ознайомлення користувача 3 рекламою. Використання таких програм в перспективі повинно стати професійним стандартом.

Також повинна бути змінена технологія оцінки ефективності цифрових рекламних кампаній. У теперішній час більшість рекламодавців для оцінки 
ефективності використовують показник CRT (клікабельність), оскільки він легко розраховується. Проте, факт кліку не гарантує ознайомлення 3 рекламною продукцією. Тому необхідно розробити дійсно ефективну систему показників.

7) Проблема збільшення кількості мобільних пристроїв (смартфонів і планшетних комп'ютерів) на противагу стаціонарним комп'ютерам. Кількість власників смартфонів і планшетів зростає з високою швидкістю: за останній рік темп зростання кількості смартфонів склав 40\%, планшетів 300\%. 3 цих пристроїв проглядається 13\% всіх Інтернет-сторінок, і частка таких переглядів зростає високими темпами. Частка мобільного маркетингу зараз становить біля 8\% від всієї цифрової реклами при щорічному темпі зростання 92\%. Приблизно 13\% всіх транзакцій в електронній комерції в період зимових свят проводяться через мобільний телефон та інші портативні гаджети (70\% з них через планшети). В цілому зростання мобільної комерції становить близько $30 \%$ на рік.

Мобільні та портативні технології радикально змінюють поведінку споживачів. Виникає ефект шоурумінга - споживачі в реальному магазині обирають товар і тут же, з торговельного залу, замовляють його через мобільний пристрій в Інтернет-магазині. Враховуючи цю тенденцію агенція ComScore оголосила про запуск бета-версії Media Metrix ${ }^{\circledR}$ Multi-Platform програми, яка дозволяє одночасно фіксувати користувачів, які переглядають рекламу зі стаціонарних комп’ютерів, смартфонів і планшетів. Виявилось, що споживачі стали використовувати смартфони для отримання інформації, пов'язаної з роздрібними покупками на 50\% частіше. Шоурумінг стає одним 3 чинників зниження цін в роздрібній торгівлі.

8) Проблема медіапланування 3 врахуванням різних цифрових платформ. Якщо раніше планування Інтернет-реклами обмежувалось лише однією платформою, то тепер одну і ту саму цифрову рекламу можна подивитись на мобільних пристроях, стаціонарних комп'ютерах, ноутбуках, планшетах, по телебаченню. Було проведене дослідження щодо перегляду спортивних змагань з використанням телевізорів, домашнього Інтернет, смартфонів, планшетів і виявлено ефект мультиплатформенного споживання. Результати засвідчили, що $25 \%$ часу трансляцій, глядачі всіх вікових категорій переглядали паралельно на екранах двох і більше пристроїв. Тобто, поява новітніх пристроїв не означає, що ефективність традиційних носіїв знижується і вони перестають бути актуальними. Така тенденція ускладнює процес управління медіаплануванням: по-перше, сучасні медіаплани повинні враховувати мультиплатформенну природу комунікативного сприйняття; подруге, при оцінці ефективності реалізації медіапланів необхідно розраховувати локальний ефект по кожній цифровій платформі.

Висновки. Цифровий маркетинг збагатив Інтернет-маркетинг, перш за все, можливостями мобільного зв'язку. Це дозволило розірвати замкнутий простір віртуального світу і увійти в реальне середовище. В результаті з'явились додаткові можливості розширення аудиторії маркетингого впливу за рахунок власників засобів мобільного зв'язку з одночасним забезпеченням 
адресності та персоніфікації такого впливу, підвищується ефективність маркетингової діяльності в умовах інформатизації суспільства.

Цифровий маркетинг збагатив Інтернет-маркетинг, перш за все, можливостями мобільного зв'язку. Це дозволило розірвати замкнутий простір віртуального світу і увійти в реальне середовище. В результаті з'явились додаткові можливості розширення аудиторії маркетингого впливу за рахунок власників засобів мобільного зв'язку з одночасним забезпеченням адресності та персоніфікації такого впливу, підвищується ефективність маркетингової діяльності в умовах інформатизації суспільства.

\section{Лiтература:}

1. QFINANCE Dictionary | Business Dictionary Online | Financial Dictionary Online QFINANCE [Электронный ресурс] / QFinance - The Ultimate Online Financial Resource. Business, economics, banking terms and accounting dictionary and glossary, 2012 - Режим доступа: http://www.qfinance.com/dictionary /digital-economy, свободный. - Загл. с экрана. — яз. англ.

2. Australian Government. Department of Broadband, Communications and the Digital Economy [Электронный ресурс] / Digital Economy: Future Directions, 2009. - Режим доступа: http://www.dbcde.gov.au/digital_economy/what_is_the_digital_economy, свободный. — Загл. с экрана. - яз. англ.

3. Ринок смартфонів в США i світі [Електронний ресурс] - Режим доступу: http://geektimes.ru/post/120734.

4. Обзорный доклад про облачные технологии и платформу Windows Azure [Електронний ресурс] — Режим доступу: http://www.oszone.net/18431.

5. Національний інститут стратегічних досліджень при Президентові України. Перспективи розвитку ринку хмарних обчислень в Україні: переваги та ризики. Аналітична записка [Електронний ресурс] - Режим доступу: http://www.niss.gov.ua/articles/1191.

6. Новые задачи вынуждают ЕСМ анализировать большие данные [Електронний ресурс] — Режим доступу: http://www.cnews.ru/reviews/new/bi_bigdata_2014/articles/novye_zadachi _vynuzhdayut_ecm_analizirovat_bolshie_dannye.

7. У 2013 році рино бізнес-аналітики зріс на 8\%. [Електронний ресурс] — Режим доступу: http://ko.com.ua/gartner_v_2013_g_rynok_po_biznes-analitiki_vyros_na_8_105023.

8. Данько Т.П. Количественные методы анализа в маркетинге: монография / Т.П Данько, И.И. Скоробогатых. - СПб.: Питер, 2005. - 384 с.

9. Карпіщенко О.О. Цифровий маркетинг як інноваційний інструмент комунікаційю. [Електронний ресурс] / О.О. Карпіщенко, Ю.Е. Логінова // Електронний архів Сумського державного університету. - Режим доступу: http://essuir.sumdu.edu.ua.

10. Каждый 5-ый человек в мире владеет смартфоном, каждый 17-ый — планшетом [Електронний ресурс] - Режим доступу:

http://vido.com.ua/article/7085/kazhdyi-5-chieloviek-v-mirie-vladieiet-smartfonom-kazhdyi-17planshietom.

11. Спеціалізоване агентство контент-маркетингу Content Marketing. [Електронний pecypc]. - Режим доступу: http://contentmarketing.com.ua/ tsifroviy-marketing-10-golovnihproblem.

12. Тренды digital-маркетинга 2014 года. [Електронний ресурс]. - Режим доступу: http://vkurse.ua/ua/ business/trendy-digital-marketinga.html.

13. Вертайм К. Цифровой маркетинг. Как увеличить продажи с помощью социальных сетей, блогов, вики-ресурсов, мобильных телефонов и других современных технологий / К. Вертайм, Я. Фенвик. - М.: Альбина-Паблишер, 2010. — 384 с. 
14. Фалгони Ж. 10 главных проблем цифрового маркетинга. [Електронний ресурс] / Жоан Фалгони. - Режим доступу: http://therunet.com/articles/923-desyat-glavnyh-problemtsifrovogo-marketinga 